
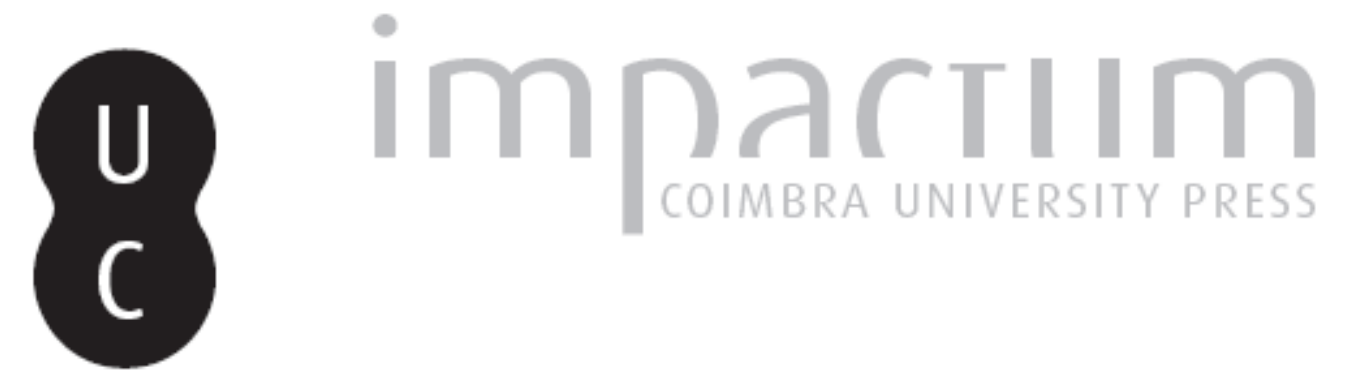

\title{
Metapoesia e crise da consciência poética
}

\section{Autor(es): Bochicchio, Maria}

Publicado por: Faculdade de Letras da Universidade de Coimbra

URL persistente:

URI:http://hdl.handle.net/10316.2/32283

DOI:

DOI:http://dx.doi.org/10.14195/0870-4112_10_6

Accessed : $\quad$ 26-Apr-2023 16:25:55

A navegação consulta e descarregamento dos títulos inseridos nas Bibliotecas Digitais UC Digitalis, UC Pombalina e UC Impactum, pressupõem a aceitação plena e sem reservas dos Termos e Condições de Uso destas Bibliotecas Digitais, disponíveis em https://digitalis.uc.pt/pt-pt/termos.

Conforme exposto nos referidos Termos e Condições de Uso, o descarregamento de títulos de acesso restrito requer uma licença válida de autorização devendo o utilizador aceder ao(s) documento(s) a partir de um endereço de IP da instituição detentora da supramencionada licença.

Ao utilizador é apenas permitido o descarregamento para uso pessoal, pelo que o emprego do(s) título(s) descarregado(s) para outro fim, designadamente comercial, carece de autorização do respetivo autor ou editor da obra.

Na medida em que todas as obras da UC Digitalis se encontram protegidas pelo Código do Direito de Autor e Direitos Conexos e demais legislação aplicável, toda a cópia, parcial ou total, deste documento, nos casos em que é legalmente admitida, deverá conter ou fazer-se acompanhar por este aviso.

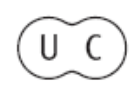



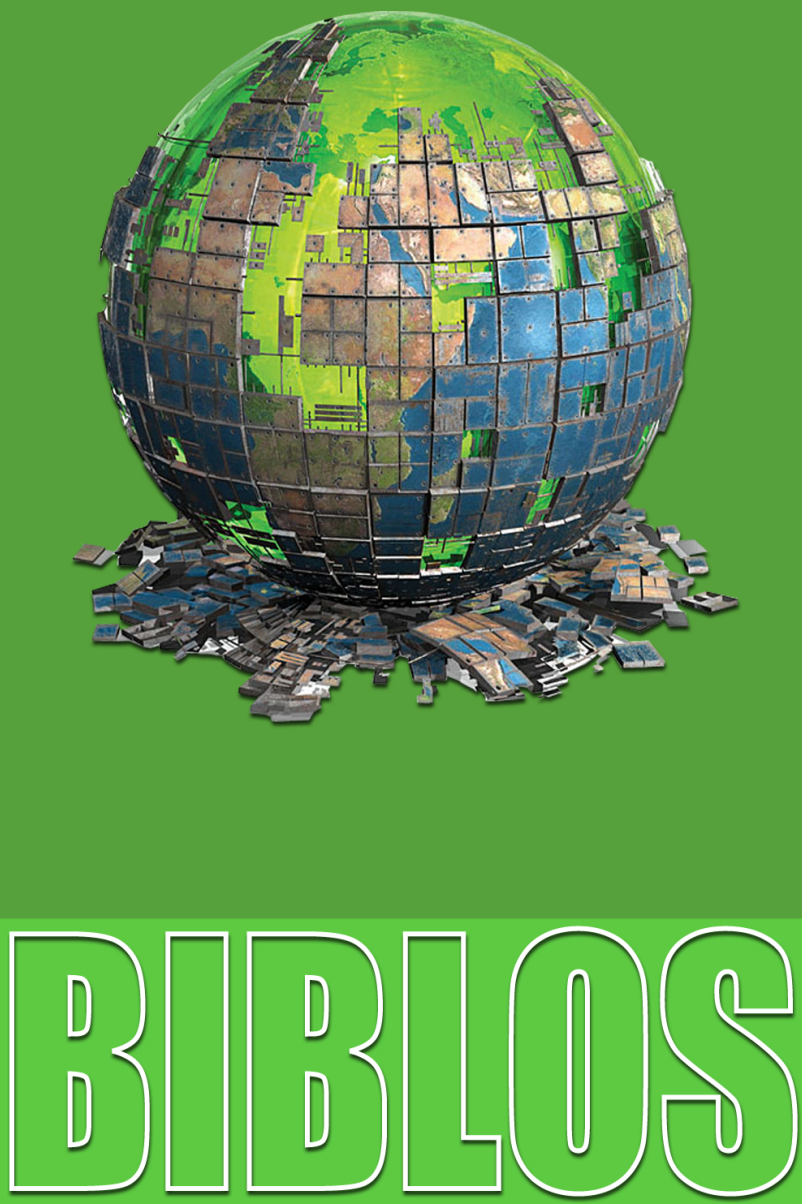

$\frac{\text { REVISTA DA FACULDADE DE LETRAS }}{\text { UNIVERSIDADE DE COIMBRA }}$ 
Biblos, n. s. X (2012) $\ldots-\ldots$

Maria Bochicchio

Faculdade de Letras da Universidade de Coimbra

\title{
METAPOESIA E CRISE DA CONSCIÊNCIA POÉTICA
}

\section{Resumo}

No texto metapoético é a própria poesia que é questionada, nas suas matrizes culturais e referenciais, nos seus pressupostos e nos seus objectivos, no elenco de interpretações ou de enigmas que suscita, no que afirma explicitamente e no que supõe ou omite. Torna-se matéria de si mesma, espelho, glosa, paráfrase, análise de processos próprios ou alheios, programa e transgressão, surpresa ou mesmo exploração do lugar-comum. O metapoema, à medida que o texto avança, vai devorando, incorporando e digerindo a ideia de que parte, amalgamando-a à linguagem que utiliza. $\mathrm{O}$ próprio tu esencial de que fala Antonio Machado, pode tornar-se a metáfora de um interlocutor supostamente fragmentado. Assim, a metapoesia torna-se um indicador irónico da crise, da perda de unidade entre a palavra e o mundo, de uma perturbação da consciência do artista. E na moderna poesia portuguesa há inúmeros exemplos dessa situação.

\section{Palavras-Chave: ...}

\begin{abstract}
In the metapoetic text, poetry itself is called into question, in its cultural and reference-related matrices, in its assumptions and goals, in the list of interpretations or enigmas it suggests, in that which it explicitly states and in that which it presupposes or leaves out. It becomes a subject matter of itself, a mirror, a comment, a paraphrase, an analysis of its own processes or those of others, program and transgression, surprise or even exploring common ground. As the text progresses, the metapoem devours, incorporates and digests the notion it originates from, by blending it with the language it uses. The essential you that Antonio Machado speaks of can become the metaphor of a supposedly fragmented interlocutor. Thus, metapoetry becomes an ironic indicator of the crisis, of the loss of unity between the word and the world, of a disturbance in the artist's conscience. In modern Portuguese poetry there are countless examples of that situation.
\end{abstract}

Keywords: ... 
A crise na literatura do século $X X$ não se manifesta apenas na cisão do eu e na fragmentação do discurso, cada vez mais renitente em submeter-se a cânones estilísticos, a regras sintácticas ou a princípios clássicos de clareza enunciativa. O próprio revivalismo dito pós-moderno manifesta essa crise, ao deslocar os seus elementos vernaculares e as suas frequentes citações para um quadro em que os desmonta para remontá-los como nova linguagem da contemporaneidade. A crise passa mesmo a considerar a linguagem poética em si e a referir-se a ela e aos seus processos, preferindo muitas vezes tomá-la como tema da própria criação literária. Mas o desconforto vinha de longe. Como já tive ocasião de mostrar, ${ }^{1}$ podemos mesmo remontar até à tradição judaica para surpreendê-lo.

Decorre da narrativa bíblica do Génesis que em Deus há uma unidade indissociável entre o pensamento e a palavra que, sendo declarada, o expressa e o concretiza, assim criando o mundo. A palavra hebraica utilizada na criação, é é dizer a si mesmo, pensar, declarar, prometer e mandar fazer, termo este semanticamente muito mais complexo do que o genérico termo טירְְברדו «V'dbarim» (cuja raiz é «diber»), que significa falar e cuja utilização é mais tardia na Bíblia. Há, assim, dois verbos, respectivamente, «dizer» e «falar». Quando Deus «disse» (Génesis, I:3), utilizou «vaie'hi», ou seja, pensa e ordena através da palavra que o mundo seja feito. A realidade que Deus tinha pensado tornou-se concreta quando Ele a declarou através da linguagem. Mas é interessante notar que a raiz do verbo «vaie'mer» é recorrente e refere-se, quer à criação divina, quer à representação do mundo pelo ser humano. ${ }^{2}$

Antes da queda, essa indissociabilidade entre pensamento, palavra e mundo, mantém-se plenamente inteligível para o ser humano, só vindo a entrar em crise com a sua expulsão do Paraíso. A partir daí, ele torna-se consciente de uma quebra de confiança nessa correlação ontológica e abre-se um fosso entre os três pólos, pensamento, palavra e mundo.

${ }^{1} \mathrm{O}$ presente texto foi elaborado a partir da introdução à minha tese de doutoramento, A poesia na poesia de poetas portugueses, José Régio, Vitorino Nemésio, Carlos Queiroz, Eugénio de Andrade, Mário Cesariny, apresentada à Faculdade de Letras da Universidade do Porto, em Setembro de 2011.

2 Cfr. Eduardo Lourenço, «Da criação como crítica à crítica como criação», in $O$ Canto do Signo. Existência e Literatura (1975-1993), Lisboa, Editorial Presença, 1993, pp. 70-72. 
No Génesis, o processo de representação e apropriação do mundo, após a queda, é assim reiterado pelo «dizer» do ser humano.

Tem, portanto, milénios a reflexão sobre a imperfeita relação da palavra com o mundo e poderíamos fazê-la remontar à narração dos episódios bíblicos do Jardim do Éden e da Torre de Babel, uma vez que, no primeiro caso, a palavra do ser humano, depois da queda, se tornou finita e limitada, e, no segundo caso, com a fragmentação das línguas, os humanos deixaram de poder entender-se directamente uns com os outros. No episódio da Torre de Babel (לֶכָּב ,) resulta frustrada a tentativa de recuperar o «vaie'hi» primordial. Numa tradição cultural que participa em grande parte da matriz judaico-cristã e helénica, o moderno conceito de fragmentação da linguagem envolve, assim, uma longínqua variação do sentido deste episódio, ${ }^{3}$ tal como o conceito de ascese espiritual pode envolver uma tentativa de regeneração daquela babélica veleidade humana.

Se tivermos presente esse fenómeno de fragmentação, podemos dizer que a metapoesia, acarretando uma reflexão sobre a palavra poética e os seus problemas, é provavelmente tão antiga como a própria poesia.

Numa interessante hipótese quanto ao diálogo enquanto forma de linguagem em acção, Manuel Gusmão afirma que, neste sentido, «o diálogo é anterior ao monólogo; uma frase é sempre dita por dois, pelo menos; uma palavra, enquanto unidade de sentido, é o produto de um confronto ou de uma cooperação, fruto do cálculo e do acaso, a resultante de uma negociação [...]». ${ }^{4}$

Cremos que poderia dizer-se algo semelhante em relação à possibilidade de o poema reflectir sobre si mesmo e dialogar com os seus próprios processos ou com sinais ou vestígios deles, isto é, em relação a uma dialogia que ocorre com frequência no interior do poema, supõe inúmeras pistas, modelos, tradições e transgressões, e postula ainda uma capacidade de enunciar essas matérias e outras afins como matérias também do próprio texto poético, num jogo de espelhos,

${ }^{3}$ François Ost nota, a respeito deste episódio: «Paradigme de tout texte à traduire, il ne nous apparaît pas comme porteur d'un sens inaltérable fixe a priori, mais plutôt en attente de reconstructions herméneutiques qui en feront, à chaque opération, un original provisoire» (Traduire / Defense et Illustration $d u$ Multilinguisme, Paris, Fayard, 2009, p. 27).

${ }^{4}$ Manuel Gusmão, Uma Razão Dialógica. Ensaios sobre Literatura, a sua experiência do Humano e a sua Teoria, Lisboa, Edições Avante, 2011, p. 377. 
de vasos comunicantes, de reversões e de reenvios cujo grau de evidência é muito variável. ${ }^{5}$ Herberto Helder parece referir-se à mecânica desse fenómeno no próprio terreno da escrita poética quando fala da «Caneta do poema dissolvida no sentido / primacial do poema. / Ou o poema subindo pela caneta, / atravessando seu próprio impulso, / poema regressando.» ${ }^{6}$

No texto metapoético, é a própria poesia, no acto de produção da escrita (e leitura) do poema que é posta em questão: as suas matrizes culturais e referenciais, os seus objectivos directos ou indirectos, os seus potenciais de ser interpretada ou de permanecer enigmática, aqueles ou aquilo que interpela, aqueles ou aquilo que rejeita, o que vai buscar e o que omite - tudo isso e muito mais pode ser verificado, intuído ou interpretado como pertencendo a um campo metapoético que pode ser também «metacrítico». Não há assim, propriamente, uma cisão entre poesia e metapoesia. O que acontece é que, nesta, temos a poesia tomada como matéria de si mesma, espelhada no poema, colocada em abismo nele, glosada nas suas virtudes e nos seus defeitos, misto de programa, constatação, surpresa, ou mesmo decepção, no trabalho poético. No metapoema, à medida que o texto avança, vai devorando, incorporando e digerindo a ideia de que parte, amalgamando-a à linguagem que utiliza. Haroldo de Campos diz que o poeta «é levado a poetar pelo próprio acto de poetar, isto é, mais do que por função referencial ou outra, ele é complementarmente movido por uma função metalinguística: escreve poemas críticos, poemas sobre o próprio poema ou sobre o ofício do poeta». ${ }^{7}$

${ }^{5}$ Manuel Gusmão enuncia duas proposições que interessa registar: i) A literatura fala de si própria, mas só o pode fazer falando de outras coisas, e isso acontece mesmo quando estamos perante textos literários que são simultaneamente textos de poética. ii) «A função de representação da literatura só pode efectuar-se ou ter efeito na medida em que ela se articula (poderíamos mesmo dizer que supõe ou comporta) uma dimensão auto-representativa ou auto-reflexiva; ou seja, na medida em que inscreve e mostra os protocolos ou as condições de possibilidade da referida função; mesmo nos casos em que o que um texto diz e aquilo que mostra não são rigorosamente coincidentes» (Uma Razão Dialógica, p. 75-76).

${ }^{6}$ Herberto Hélder, Ou o poema contínuo, Lisboa, Assírio \& Alvim, 2001.

${ }^{7}$ Cit. por Nádia Battela Gotlib no seu livro O Estrangeiro Definitivo / Poesia e Crítica em Adolfo Casais Monteiro (Lisboa, IN - CM, 1985, p. 28). 
Valha o que valer cada um dos episódios bíblicos acima referidos, deles decorre uma consciência da «opacidade» da linguagem para abarcar o mundo que se mantém até aos nossos dias, seja no plano da reflexão filosófica, seja no da experiência literária, fazendo-se sentir muito em especial no que respeita à palavra poética. O poeta vê-se, assim, confrontado entre a vontade de dizer («vaie'hi») o mundo, ditando ou comandando as suas próprias regras, e a fragmentação de uma linguagem incapaz de expressar a unidade perdida. Isso implica que reflicta sobre aquilo que faz enquanto o faz - daí a metapoética. Foi por terem intuído a cisão assim operada nessa unidade primordial do Ser que os Simbolistas, cuja poética domina apesar de tudo e em várias combinações e dosagens com outras correntes literárias, grande parte do século XX, expressaram, de vários modos, uma nostalgia dessa unidade ontológica que de algum modo já se encontraria em Hölderlin, no dizer de Heidegger: «L'être de l'homme a son fondement dans le langage» e também que «La poésie est fondation de l'être par la parole». Heidegger considera essencial a metapoesia de Hölderlin: «ce qui formele support de la poésie de Hölderlin c'est cette détermination poétique qui consiste à poématiser expressément l'essence de la poésie elle-même. Hölderlin est pour nous, en un sens privilégié, le poète du poète». ${ }^{8}$

Na poesia de língua inglesa, a validade do conceito e da prática simbolistas é porventura mais limitada, uma vez que a ironia, a desarticulação da percepção, o sarcasmo e a experimentação se afirmaram, questionando a pretensão e a propensão simbolistas, mais cedo do que no continente europeu, e reflectindo no interior do poema sobre a própria arte deste. "His true Penelope was Flaubert", escreve Ezra Pound no poema "E. P. Ode pour l'élection de son sepulchre", em que, por uma espécie de sinédoque encadeada, revisita uma literatura de todos os tempos e manifesta a sua decepção e a sua consciência de ter falhado: "For three years, out of key with his time, / He strove to ressuscitate the dead art / Of poetry; to maintain 'the sublime' / In the old sense $[\ldots] "$

${ }^{8}$ Martin Heidegger, Erläuterungen zu Hölderlins Dichtung, trad. fr., Approche de Hölderlin, Paris, Gallimard, 1962, em especial «Hölderlin et l'essence de la Poésie», pp. 41-61. 
Precisamente, evitando o recurso ao conceito "escolástico" de Simbolismo, Hugo Friedrich escrevia, já em 1956, que os poetas simbolistas, com Mallarmé à cabeça, "apresentam características que são também características actuais, tais como se encontram em Valéry, Guillén, Ungaretti, Eliot, Trakl", embora para assinalar que o conceito de simbolismo "define um estilo poético de maneira absolutamente insuficiente". . O poeta deixará de escrever para a eternidade, contemplando um futuro um tanto ou quanto ignorado, ante o qual a obra só pretende ser "uma experimentação provisória"

Há quem veja outro aspecto da questão na perda de uma função social e colectiva da poesia, na altura em que os textos prosaicos, por força de uma pan-helenização, se agrupavam reunindo várias tradições locais, a fim de homogeneizá-las. Para Andrew Ford, é nessa época, por alturas do século $\mathrm{V}$ a. $\mathrm{C}$., que a poiesis ganha um sentido muito preciso, o de que «un chant local ne compte plus en tant que moment rythmant la vie d'une communauté réelle, mais en tant qu'exemple de la créativité d'une communauté ideologique». ${ }^{11}$ Isso obriga a poesia a repartir-se por géneros poéticos. Maxime Laurent, servindo-se da hipótese de Ford que acabamos de citar, considera o género em sentido arcaico muito próximo das definições hoje propostas pelas análises do discurso e define-o como «un ensemble de régularités intra-discursives (de contenu comme d'expression), dans la mesure où celles-ci renvoient à l'extra-discursif - disons, à une 'acceptabilité', ou à des conventions sociales d'énonciation et de réception». E assim, na época arcaica, «les noms par lesquels les Grecs classaient leurs chants se référaient toujours à des découpages très nets de la pratique sociale - à différentes occasions de chant». ${ }^{12}$ Com a passagem da oralidade à escrita, os critérios textuais ganham peso contra a função colectiva, ou, como diz Maxime Laurent,,$^{13}$ despojado da sua dimensão extra-

${ }^{9}$ Hugo Friedrich, La Struttura della Lirica Moderna (trad. italiana), Milão, Garzanti, 2002, p. 149.

${ }^{10}$ Id., ibid., p. 150.

${ }^{11}$ Cit. por Maxime Laurent, «L'occasion perdue: Callimaque et Segalen, deux poètes en puissance», in Anne-Elisabeth Halpern e Christian Doumet (coord.), Ce que le poème dit du poème, Saint-Dennis, Presses Universitaires de Vincennes, 2005, p. 190.

${ }^{12}$ Maxime Laurent, op. cit., pp. 190-191.

${ }^{13}$ Ibid. 
-discursiva própria, um poema deixa de ter valor pragmático definido e acaba por tornar-se um género literário, só se distinguindo dos outros por um conjunto de marcas textuais. Pode por isso ver-se na criação e estabilização dos géneros uma primeira manifestação de metapoesia, isto é, uma primeira reflexão do poeta sobre o poema ou do poema sobre si mesmo, e por uma funcionalidade própria - e literária - dos discursos que incorporam e fazem defrontar-se esses vários géneros.

Os casos bíblicos e o caso helénico referidos apontam para uma «perda» ou um «handicap» da linguagem, no tocante à sua relação com o mundo, o primeiro tendo em conta o desentendimento universal e o segundo o esvaziamento de uma primitiva função social dos textos. Em ambos se considera uma crise da linguagem e este aspecto gera uma desconfiança intelectual em relação aos poderes dela para designar o mundo. A filosofia grega ocupou-se do problema, em especial sobre o modo como as palavras representam as coisas, exprimem modalidades do pensamento e tornam possível a aquisição e a elaboração do conhecimento.

Como escreve Steiner, em Real Presences, «a crise da linguagem converteu-se num facto de consciência». ${ }^{14}$ Por outro lado, é conhecida a desconfiança que, desde Platão, a filosofia grega nutriu em relação à poesia e à linguagem, aquela, socialmente nociva, veículo de falsidades e desrespeito dos deuses, e esta, uma enganadora convenção ficcional, uma vez que por ela o homem designa uma realidade aparente em si mesma. ${ }^{15}$

Em todo o caso, há uma diferença essencial entre Platão e Aristóteles: como nota Manuel Gusmão, que faz uma síntese do pensamento de ambos na matéria, «ao invés de Platão, Aristóteles procede a uma valorização gnoseológica da mimese poética» e, além disso, «a mimese parece constituir uma característica antropológica duplamente distintiva», sendo o imitar em si uma forma de aprendizagem congénita

${ }^{14}$ Cit. por Ramón Pérez Parejo in Metapoesia y Critica del Lenguaje (De la Generación de los 50 a los Novísimos), Cáceres, Universidad de Extremadura, 2002, pp. 44-45.

${ }^{15}$ Seguiremos neste rápido excurso, embora muito por alto e de forma muito abreviada, a exposição de Ramon Pérez Parejo na obra citada na nota anterior (pp. 42 e segs.). 
no homem e o homem compraz-se no imitado, tendendo a imitação a ser aproximada da noção de representação. ${ }^{16}$

A desconfiança ou suspeição quanto à poesia atenua-se na Idade Média, dada a sua pretensão de não dissociar a razão e a fé e a sua ambição de que tudo possa perfazer um sentido subsumível no seio de Deus sem quaisquer ambiguidades. Tal finalismo explicava-se exactamente por Deus ser o criador de todas as coisas, embora, mais tarde, o nominalismo de Guilherme de Occam (século XIV) se volte contra as construções da Escolástica e o seu dogmatismo. Deixa então de haver confiança na linguagem e numa sua pretensa univocidade.

Entretanto, do Renascimento ao Barroco, a confiança no homem e o seu progressivo resvalar para uma concepção pessimista, repressiva e pós-tridentina do ser humano; a deslocação de uma cultura optimista, assente na dignidade humana, no trato com os clássicos gregos e latinos, no módulo ideal do corpo humano e da beleza física e no desvendamento do mundo com o consequente alargamento da ecúmena, isto é, da área habitada da terra que passa a ser conhecida, para uma cultura do pessimismo, da desilusão, do desengano e da necessidade de expiação do pecado, sob a férula da Inquisição e do Estado absoluto; a transição de uma concepção do equilíbrio das formas estéticas para uma concepção do desequilíbrio em que passam a surgir - tudo isso provoca, por um lado, um afastamento e um rebuscamento progressivos da linguagem literária em relação a uma linguagem da naturalidade quotidiana, e, por outro, implica um debate metaliterário sobre os limites entre a ficção e a realidade.

É nesse quadro que os problemas da imitação e da originalidade na composição literária ganham valências por vezes contraditórias, criando novas instâncias de legitimação, como a variação, a tradução, a paráfrase e a glosa de textos pré-existentes, num jogo de reenvios ilimitados que aspira a uma reversão entre a linguagem e o mundo. O espírito humano, que no Renascimento se propunha como a medida de todas as coisas, passa, a partir de meados do século XVI, a alimentar uma dúvida angustiada sobre todas as coisas. Em contrapartida, o equilíbrio procurado dos factores em presença é substituído pela distorção, pelo alongamento, pela anamorfose do Maneirismo e, em seguida,

${ }^{16}$ Manuel Gusmão, Uma Razão Dialógica. Ensaios sobre Literatura, a sua experiência do Humano e a sua Teoria, Lisboa, Edições Avante, 2011, pp. 61-64. 
pelo lúdico em todos os seus aspectos verbais e até gráficos. No Barroco, o conceptismo, as agudezas, a arte de engenho, a exploração dos reflexos e da vanidade de tudo, a concepção do mundo como teatro e ilusão, manifestam um jogo de enganos e decepções entre a linguagem e a realidade em que la vida es sueño e o sonho, literatura.

Sendo pouco produtivo percorrer em síntese todas as etapas históricas do problema, limitemo-nos a assinalar que, para Heidegger, o próprio ser da poesia, característico da criação poética de Hölderlin, é encarado numa perspectiva ontológica: esse tipo de reflexão metapoética torna-se uma saída para o transcendente e a finalidade da poesia será a de dar o nome às coisas, criando uma relação entre a palavra humana e a esfera do divino: «É por isso que, no tempo da noite do mundo, o poeta diz o sagrado. É por isso que a noite do mundo é, no idioma de Hölderlin, a noite divina». ${ }^{17}$ Por sua vez, Wittgenstein formula em termos revolucionários a questão das relações entre a linguagem e o mundo, sendo este o conjunto daquilo que pode dizer-se: «os limites $d a$ minha linguagem significa os limites do meu mundo» (Tractatus, 5.6).$^{18}$

Ao longo de todos os séculos que tão brevemente recapitulámos, prescindindo de nos determos na floresta de teorias linguísticas que poderiam ser convocadas, a reflexão da poesia sobre si mesma pôde organizar-se de várias formas, atingindo por vezes, e sobretudo na época moderna, o cerne desse questionamento dos poderes da linguagem que, de algum modo, se veio manifestando, quase sempre em termos de desconfiança em relação a ela. Até porque, na passagem da oralidade à escrita, a demanda do significado se torna uma questão premente e leva a poesia à interrogação de si mesma. É também desde os Gregos que vem a desconfiança em relação à escrita e à possibilidade, ainda mais problemática e precária, de, nela, a palavra designar o mundo.

Nesse sentido, há quem sustente, como Letoublon e Herzberger, que a metaliteratura é um fenómeno muito antigo, encontrando-se tanto nos primórdios da literatura grega (a composição circular da Ilíada e o Canto XIX da Odisseia) como em obras dos séculos XVII e XVIII

\footnotetext{
${ }^{17}$ Heidegger, «Para quê poetas?», in Caminhos da Floresta, Lisboa, Fundação Calouste Gulbenkian, 2002, p. 312.

${ }^{18}$ Ludwig Wittgenstein, Tratado Lógico-Filosófico e Investigações Filosóficas, Lisboa, Fundação Calouste Gulbenkian, 1987, p. 114. Respeitou-se o itálico e a aparente falta de concordância da forma verbal «significa».
} 
(Quijote, Tristram Shandy, Jacques le Fataliste, Tom Jones), e quem defenda a tese contrária, como Octávio Paz ou Carlos Bousoño, para quem, sendo a poesia moderna também teoria da poesia, tal modernidade é implicada por esse carácter auto-reflexivo. ${ }^{19}$

Cremos que deverá enquadrar-se a diacronia do fenómeno, distinguindo entre os períodos em que existiu e foi observada, explícita ou implicitamente, a preceptística normativa das «artes poéticas» mais ou menos clássicas, de Horácio a Boileau, e a época que se inicia no Romantismo. ${ }^{20} \mathrm{~A}$ irrupção deste instabiliza o conjunto harmónico em que a expressão e a beleza resultam do «ajustamento da razão e da sensibilidade, da intenção e da forma, do espírito e da matéria» e «desequilibra a balança, buscando-as na aceitação, no aproveitamento, na exploração e na expansão desse desequilíbrio». ${ }^{21}$ Efectivamente, a partir do Romantismo, ou logo que surge uma ruptura com ele, e entrando pelo século XX dentro, cada poeta é livre de engendrar os próprios princípios de configuração da sua arte, combinando-os ou não com modelos anteriores e procedendo, em muitos casos, a uma auto-reflexão metaliterária que lança mão desse princípio como material temático e/ou estruturante do poema.

Por outro lado, a desconfiança, quer na linguagem, quer nas possibilidades do poema, bem como a evolução e o aprofundamento dos estudos linguísticos, levam a uma mais intensa preocupação com a auto-referencialidade, sem contar com os efeitos miméticos e epigonais do fenómeno. Mas é certo que poderemos também, em certa medida, falar em confiança, se não na linguagem, pelo menos na poesia, sempre que esta é tomada como tema ou problema em si, ou como instância de autotelismo poético, isto é, como fim em si mesma, ou ainda quando se propõe aflorar ou indagar do seu próprio mistério.

${ }^{19}$ Cfr. Leopoldo Sánchez Torre, La Poesia en el Espejo del Poema / La Práctica Metapoética en la Poesia Española del Siglo XX, Oviedo, Departamento de Filologia Española, 1993, pp. 70-71, e autores aí citados.

${ }^{20} \mathrm{Cfr}$. a este respeito e quanto à poesia lírica, em especial do período que vai do Renascimento até ao século XVIII, Gustavo Guerrero, Poétique et Poésie Lyrique, Essai sur la Formation d'un Genre, Paris, Editions du Seuil, 2000.

${ }^{21}$ José Régio, Pequena História da Moderna Poesia Portuguesa, Lisboa, Inquérito, 1941, p. 7. 
Identicamente, devemos notar a importância e a frequência que a partir de Baudelaire o «tema» da poesia - e portanto a metapoesia passou a ter na poesia portuguesa (e não só), e de modo especial na poesia do século XX.

Temos assim a metapoesia, quer como expressão de uma inquirição teórica sobre a poesia ou o poema, quer como manifestação de uma arte poética pessoal, enunciado de princípios, ou ainda perspectiva crítica em geral ou em causa própria, quer ainda como metáfora em que a poesia fala de si mesma para falar também de outra coisa (por exemplo, a «ars poetica» como «ars vivendi»). De notar também que o metapoema aspira a ser lido como poema de pleno direito, embora sem prejuízo da consciência oficinal de que o discurso correspondente teoriza criticamente e como tal pode ser utilizado.

Depois de falar na poesia, enquanto «palavra inspirada que investe miraculosamente o homem, segundo Platão, ou bloco, futuramente enigmático e obscuro, para Mallarmé», Eduardo Lourenço escreve: «Assim e, na aparência, para sempre, a criação se coloca sob o olhar da crítica, quer dizer, é interrogada acerca da relação que possa ter com o sujeito que se fala nela e a realidade que aí é falada». Ora, acrescentemos, esse olhar da crítica pode ser um dos ingredientes do próprio poema. Nestes termos a metapoesia releva como processo de conhecimento estético, por via de uma multipolarização de tensões que a convertem em projecto cognoscitivo e num resultado semanticamente complexo, reformulando os hábitos de leitura, uma vez que exige a cumplicidade do leitor. E ao fazê-lo, o metapoema proporciona um mais fecundo conhecimento da poesia e, por extensão, do mundo.

Talvez devesse ainda observar-se que é logicamente discutível a razão de ser de lexemas como «metapoesia» e «metapoética», no contexto em que, por vezes, a teoria literária e a crítica os usam hoje em dia. Na verdade, uma coisa é conceber a metalinguagem literária como o conjunto daqueles textos nos quais se comentam, analisam, caracterizam ou de qualquer modo discutem «as convenções, as regras, os mecanismos semióticos que subjazem aos processos de produção, estruturação e recepção dos textos literários», ${ }^{22}$ outra coisa é designar como metaliterário ou metapoético o poema que promove a sua auto-

${ }^{22}$ Vítor Manuel de Aguiar e Silva, Teoria da Literatura, Coimbra, Almedina, 1982, pp. 110-111. 
-referencialidade, uma reflexão sobre si mesmo ou uma incursão afim, sobre a poética ou o poeta. E podemos mesmo distinguir entre o poema estrutural ou centralmente metapoético, ou só pontual ou acidentalmente metapoético, assim como podemos falar numa metapoesia consciente, elaborada, voluntária - não só explícita -, em contraste com outra, de aparência espontânea, involuntária, aleatória.

Neste segundo caso, não se trata de designar assim uma realidade que esteja para além da poesia ou seja exterior a ela conquanto centrada sobre uma dada prática da literatura, como o prefixo meta- poderia sugerir. Muito pelo contrário, a realidade considerada encontra-se no próprio cerne do fenómeno poético enquanto actividade consciente de produção literária. Quando a poesia é matéria da própria criação poética é exactamente isso que se verifica. Se o poeta escreve sobre a poesia, ou sobre o poema, ou sobre si mesmo enquanto poeta, nada do que faça é exterior à poesia ou está para além dela...

Depois de observar que a metalinguagem literária se manifesta «necessariamente sob a forma de uma poética explícita», V. M. Aguiar e Silva sustenta que admitir «a existência de uma 'metalinguagem literária implícita' equivale a cair no erro de uma contradictio in terminis, pois o conceito de metalinguagem implica o conceito de 'explicitude'», embora admita que a consciência literária do autor possa «manifestar-se, quer sob a forma de uma poética explícita, quer sob a forma de uma poética implícita, ${ }^{23}$ isto é, não explicitamente teorizada, mas defluente da própria realização dos textos literários». ${ }^{24}$

Curvemo-nos todavia ao uso já consagrado e consideremos essas designações do campo da metaliteratura como integradas no próprio conceito de literatura. ${ }^{25}$ Essa auto-referencialidade, mais do que um tema entre outros, será, para alguns teóricos,

${ }^{23}$ Leopoldo Sánchez Torre opina que «'la metaliteratura implícita' no existe sino como construcción del analista», para concluir: «en definitiva no hay 'metaliteratura' implícita» (op. cit., p. 69).

${ }^{24}$ Aguiar e Silva, op. e loc. cits.

${ }^{25}$ Damos um exemplo apontado por Nádia Battela Gotlib no seu livro O Estrangeiro Definitivo. Poesia e Crítica em Adolfo Casais Monteiro (Lisboa, IN-CM, 1985, p. 28): «René Wellek escreve: “... alguns poetas tentaram na sua poesia falar da poesia e do poeta: criar qualquer coisa que foi chamada 'meta-poesia' quando falamos de 'meta-linguagem'. Esta 'meta-poesia' preocupa-se em 
una cuestión de génesis, ontológica, epistemológica y existencial, ya que se desconfia de la capacidad del lenguaje para conocer el mundo y reflejarlo, y en esse arriesgado juego también se cuestiona la función del próprio tanto en la soledad de su alcoba como en la sociedad. ${ }^{26}$

Muito embora este quadro pareça ser desmentido, pelo menos pelos poetas cujas poéticas têm implícito um propósito de transformação do mundo, a verdade é que, pelo menos depois da Carta de Lord Chandos, de Hugo von Hoffmannsthal (1902), no dealbar do século XX, se agravava uma crise da linguagem e das artes (que, no plano da literatura, podemos fazer remontar a Baudelaire e a Edgar Poe), levando a que se sentisse o esgotamento ou a impossibilidade de dizer o que quer que fosse pela literatura. Isto, como observa Pierre-Antoine Hure, 15 anos antes da publicação do Cours de Saussure, 20 anos antes do Tractatus de Wittgenstein e do Ulisses de Joyce, 30 anos antes da primeira parte do Homem sem Qualidades de Musil, «et presque le double avant les pièces de Beckett s'efforçant de dire 'l'innommable', ou l'épineuse floraison du Nouveau Roman». ${ }^{27}$

Basta portanto um simples olhar sobre a poesia do século que passou para nos darmos conta da frequência e do protagonismo das formas e dos processos auto-reflexivos e auto-referenciais, não só na poesia e na literatura, mas nas artes em geral. De resto, como vimos, este tema não é dos mais recentes dentro de uma perspectiva metaliterária alargada. É um facto que tal perspectiva se manifestou em todas as épocas como confiança (por vezes...) nos poderes da palavra ou como necessidade crítica. Como exemplo do primeiro caso, poderíamos citar o Horácio de "Exegi monumentum aere perennius" (Odes, III, 30) e, para o segundo, recordar o Dante da Vita Nuova, obra que Edoardo Sanguinetti classifica "como um discurso sobre teoria lírica, porquanto

grande medida com a auto-definição do poeta e com a sua missão ou função"» (trad. nossa).

${ }^{26}$ Ramón Pérez Parejo, Metapoesía y Ficción: Claves de una Renovación Poética (de la Generación de los 50 a los Novísimos), Madrid, Visor Libros, 2007, p. 13.

${ }^{27}$ Pierre-Antoine Hure, Savons-nous lire Hofmannsthal? La lettre de Lord Chandos cent ans après, Paris, Klincksieck, 2004, p. 12. 
história de um discurso poético velada sob a capa do romanesco". ${ }^{28}$ Mas Dante vê também em Arnaut Daniel "il miglior fabbro del parlar materno" (Purg., XXVI), colocando dentro do poema a própria questão identitária da língua vernácula do poeta na sua relação com o artifício literário, enquanto Guillaume de Machaut (1300-1370) propunha, poucas décadas mais tarde, uma coordenação do sentido, da retórica e da música na consecução dos objectivos da criação poética:

Par Sens aras ton engin enfourmé

De tout ce que tu vourras confourmer;

Rétorique n'ara riens enfermé

Que ne t'envoit en metre et en rimer;

Et Musique te donra chans,

Tant que vourras, divers et deduisans.

Ainsi ti fait seront frique,

N'a ce faire ne pues estre faillans

Car tu as Senz, Retorique et Musique. ${ }^{29}$

Podendo, assim, admitir-se que, numa perspectiva histórica, a questão é tão antiga como a própria poesia. É evidente que não foi só a modernidade que valorizou a perspectiva metaliterária, mas crê-se que só a modernidade autonomizou a metapoesia como via artística a se, chamando a atenção, tanto para a necessidade teórica de indagar sobre a génese do acto criativo, os seus fundamentos, os seus pressupostos, os seus pentimenti, rasuras e reelaborações e as suas finalidades, como para uma praxis correspondente e a correlativa expressão existencial, problematizando em ambos esses planos o poder comunicativo da linguagem e o valor da ficção poética. Isto é, dir-se-ia que nunca, como no século XX, essas questões se tinham apresentado de forma tão explícita e decisiva, desse modo tornando possível analisar algumas peculiaridades e tendências mais reveladoras e produtivas da poesia contemporânea. É no mesmo sentido que Hugo Friedrich escreve que

${ }^{28}$ Rita Marnoto, A Vita Nuova de Dante Alighieri. Deus, o amor e a palavra, Edições Colibri e Fac. De Letras da Universidade de Coimbra, 2001, p. 101. Segundo Petrocchi, a prosa do texto dantesco "não é susceptível de ser desvinculada daquele complexo poético" (Marnoto, ibid.).

${ }^{29} \mathrm{Cfr}$. Michèle Gally (dir.), Oc, oül, si.Les langues de la poésie entre grammaire et musique, Paris, Fayard, 2010, pp. 188-189. 
"a partir de Poe e Baudelaire, os poetas desenvolvem uma reflexão poética sobre a poesia que procede paralelamente à sua obra". ${ }^{30}$

Analisar a reflexão da poesia sobre si mesma significa analisar uma necessidade ontológica, epistemológica e existencial, afinal concomitante com o próprio acto da escrita. Essa reflexão implica uma necessidade cognitiva e supõe no poema a forma legítima de realização de um conhecimento do mundo que é da ordem do estético. De facto, a metapoesia representa um instrumento de autoconhecimento do sujeto poético e da sua linguagem no poema, tanto quanto uma maneira de entender o mundo através das instâncias de uma auto-referencialidade da palavra poética. Esta reelabora a experiência humana no processo poético, do mesmo passo que questiona o seu próprio fazer (poiein) enquanto agenciamento eficaz de saber e técnica, propondo a ficção verbal a que chega como categoria ou, pelo menos, interpelação da realidade.

O poeta contemporâneo, diferentemente do poeta do século XIX, que na sua metapoética revelava principalmente um desejo ou um rasgo de autonomia criativa emancipadora e de contraposição a escolas que o tinham antecedido, enfrenta, a partir do Romantismo e em particular a partir de Baudelaire, Rimbaud e Mallarmé, o ser e o funcionamento da linguagem poética em termos de crise, de negação, de exílio, de vazio, de silêncio que pode ser simbolizado pela ausência da palavra. Esta crise profunda da linguagem que se manifesta, entre outros aspectos, na fragmentação, no desconjuntamento, na incapacidade dela para dar conta do mundo, na dissociação entre palavra e pensamento, na incapacidade de comunicar plenamente tanto a realidade como a experiência, leva a várias soluções estéticas: a metapoesia em primeiro lugar, mais tarde a poesia experimental e, por fim, a poética do silêncio. Três respostas distintas, mas inter-relacionadas entre si. Enquanto a linguagem manifesta, directa ou indirectamente, a sua incapacidade para expressar os sentimentos, descrever o mundo e nomear a realidade, o discurso poético centra-se sobre si mesmo e desvenda as próprias teorias e estratégias de composição do texto, fazendo delas a sua própria matéria e engendrando todo um jogo de ficções.

${ }^{30}$ H. Friedrich, op . cit., p. 154.

Faculdade de Letras | Universidade de Coimbra 
O poeta, assim demistificado o seu estatuto de vates visionário ou romântico, entra em crise, interroga-se sobre a relação da palavra com o mundo e reflecte sobre a problemática essência da sua arte e o seu carácter fictício e/ou deceptivo. É sobretudo a partir de Mallarmé, grande propulsor da metapoesia contemporânea (o poema como ficção, a arte como engano ou máscara, a crítica da autoridade da linguagem, são alguns dos tópicos sobre os quais o poeta organiza as próprias reflexões), que este diálogo da poesia com a linguagem e a crítica intrínseca que ao mesmo tempo lhe faz se revela precisamente na medida em que toda a prática literária contém uma poética implícita.

Assim, depois das primeiras vanguardas do século $\mathrm{XX}$, os poetas têm em comum o sentimento de se moverem num espaço que foi sendo progressivamente deixado vazio, alheado das preocupações e privado dos fundamentos das correntes dos decénios anteriores, sem as suas vinculações e os seus preconceitos. Um espaço em que, por isso mesmo, a liberdade e a gratuitidade correrão mais tarde o risco de se confundir uma com a outra. Um vazio, porém, que ao mesmo tempo parece levar a uma nova focalização da dimensão literária, restaurando as suas prioridades, definindo os seus fundamentos e revendo as suas premissas e justificações.

Se o poeta cedo se apercebeu da crise de valores que marcou os inícios do século $\mathrm{XX}$, também interiorizou a crise do próprio valor poético. Por isso, é necessário compreender como é que, através do seu «fazer», ele configurou a questão de saber o que é a poesia e como é que lhe deu uma resposta. O modo como o fez pode até ser tão importante como a própria resposta.

Trata-se de uma pergunta antiga, fundamental, inquietante, complexa, na ordem de uma realidade que situa esse objecto problemático e enigmático nos alicerces instáveis em que assenta. E isso implica não só formular a pergunta, mas também procurar as estruturas, os nexos, as relações e as tensões que se sedimentam, funcionam e ocultam em torno da ideia de poesia. Essa pergunta sabemos que não é traduzível em termos diferentes daqueles em que existe. E também a resposta não é linear e unívoca.

A metapoesia, independentemente do processo no qual e pelo qual se focaliza a sua reflexão sobre a poesia, manifesta-se não só como pesquisa ambiguamente teórica sobre a poesia (uma vez que o poema é, ao mesmo tempo, ele mesmo e o instrumento dela), mas também, 
como acontece nalguns casos, como exposição de uma poética pessoal, como manifesto ou declaração de princípios, como crítica da linguagem ou da literatura ou como autocrítica. O metapoema «deslocado ou confinado» também à função de discurso teórico cria muitas vezes uma tensão entre discurso poético e o discurso crítico. E, logicamente, para além do discurso crítico e/ou valorativo, há uma tomada de posição e uma reflexão sobre a poesia, que surgem e vivem no poeta, num intermitente variar das relações segundo impulsos sempre novos e imprevisíveis.

Os novos cenários que se delinearão ao longo do século XX dir-se-iam condicionados pelos modelos modernistas. É muito provável que na primeira metade do século tenham sido realizadas todas ou quase todas as experiências temáticas, estruturais e formais que os anos posteriores irão declinar, percorrer e também teorizar, de uma forma mais sagaz e mais consciente. Nesses anos, a poesia (mas não só a poesia) conhece formas de exasperação e de conflito com o real que se prolongarão durante muito tempo. A «desumanização da arte» de que falava Ortega y Gasset levou pouco tempo a criar vagas de epígonos, mas levou muito tempo a integrar-se na consciência colectiva. E nesse quadro surgem os movimentos que defendem a poesia descomprometida e a poesia comprometida, a escrita automática e o imaginário surrealista, o experimentalismo e outras rupturas, quase sempre precárias - avultando, nessa sequência, algumas grandes figuras que, embora podendo situar-se preferencialmente neste ou naquele quadrante, acabam por ser irredutíveis a rótulos ou correntes.

É evidente que, actualmente, a identidade da poesia, a sua acentuada marginalidade e descontinuidade, o seu necessário ecletismo, a confusão entre cultura «cultivada» e cultura popular que nesse plano se realiza, tornam em primeiro lugar bastante difícil a tarefa do leitor. A chamada «promessa de arbítrio» («tudo serve» ou «qualquer coisa está igualmente bem») dos tempos que correm envolve o risco de ser uma armadilha que parece condenar-nos ao confronto, limitado e frustrante, com microscópicos nichos de experiência, auto-satisfeitos consigo mesmos, indiferentes, se não a tudo, pelo menos à esperança de que qualquer coisa não alienante seja possível ou praticável. Todos nós, poetas e críticos, usamos a única palavra poesia para dizer demasiadas coisas diferentes. Quanto à extensão da audiência, recíproca e limitada, de críticos e poetas, ocorre remeter para a ironia contundente do 
Alexandre O’Neill de «O lanterna vermelha»: «Quem nos lê a nós? São vocês (e nós...) / Quem vos lê a vocês, somos nós (e vocês...)». ${ }^{31}$ E Jorge de Sena, em 1972, fazia este diagnóstico:

Creio que uma das maiores dificuldades em que se debate a poesia portuguesa contemporânea é a abstracção, o inconcreto, a impossibilidade mental de escrever referencialmente, seja em relação ao que for. Quase toda a gente [...] vive na aflição e na inibição de não dizer nada claramente, de não mencionar nada concretamente, de não estabelecer conexões racionais e lógicas com experiência alguma - o que nada tem a ver com a liberdade da imaginação ou com a experiência linguística, e é apenas o resultado de décadas de meias palavras cifradas. ${ }^{32}$

Assim, dois grandes poetas portugueses do nosso tempo situam a crise ampliando o sentido da sua reflexão, em relação ao discurso crítico com a pungente ironia o'neilliana, e em relação à propensão para a rarefacção, para a ausência do concreto, para a evasão do real, no certeiro diagnóstico de Sena. Consolemo-nos pensando que também a grande poesia tem horror ao vazio.

${ }^{31}$ Alexandre O'Neill, «Lanterna Vermelha», Poemas com Endereço, in Poesia Completa, Lisboa, Assírio \& Alvim, 2000, p. 207.

${ }^{32}$ Nota a Exorcismos, Lisboa, Livraria Morais, 1972, p. 10. 